\title{
Building a Relationship Between Vocational Training Institutions and Enterprises in Vietnam in the Integration Period
}

\author{
Dr. Dang Van Sang ${ }^{1 *} \quad$ Dr. Luu The Vinh ${ }^{2}$ \\ 1.Ho Chi Minh city Polytechnic College, Vietnam \\ 2.Hung Vuong University, Phu Tho province, Vietnam
}

\begin{abstract}
In recent years, with the policy of international economic integration of Vietnamese government, vocational training has made many positive changes. The quality and efficiency of vocational training have been improved and trained workers have participated in almost all sectors of the national economy. The effective cooperation model between the vocational training institution (the schools) and the enterprises is the key for this sucess. We used both qualitative and quantitative approaches for analysis data. The results of descriptive statistics, Cronbach's Alpha analysis have identified and measured 7 attributes of building a relationship between vocational training institutions and enterprises. The paper discusses the relationship between the schools and enterprises in vocational training in Vietnam and make some recommendations for effectively enhancing this relationship in the coming time.
\end{abstract}

Keywords: vocational training, schools, businesses, relationships

DOI: $10.7176 / \mathrm{JEP} / 11-12-06$

Publication date: April $30^{\text {th }} 2020$

\section{Introduction}

Over the past few years, the development of vocational training and skilled - human resource has been very interested by the Social Comunist Party and the State of Vietnam and has made many positive changes. The legal system has been increasingly completed and created a full legal corridor for the development of vocational training. The network of vocational training institutions has been widely developed and diversified in terms of types, training levels and operating models.

According to a report by the General Directorate of Vocational Training, in 2019, Vietnam has 1,917 vocational training institutions including 400 colleges (301 public schools), 492 secondary schools (277 public schools) and 1,025 vocational training centers (645 public centers). The total number of public vocational training institutions is 1,223 (578 public colleges and universities) (The General Directorate of Vocational Training, 2019a).

The enrollment result of vocational training of the whole country in 5 years (from 2014-2018) was 8,781,901 people. On average per year, over 2 million people are enrolled in the whole country. In 2 years (2017-2018), more than 2.2 million people were enrolled every year, of which enrollment of college and secondary schools reached more than 540 thousand people/year (accounting for $25 \%$ of the total national enrollment); primary enrollment and other vocational training programs attracted more than 1.6 million people/year (accounting for $75 \%$ of the total national enrollment) (see table 01).

Table 1: The enrollment result of vocational training of Vietnam from 2014-2018

\begin{tabular}{|l|c|c|c|c|c|}
\hline \multicolumn{1}{|c|}{ Level } & $\mathbf{2 0 1 4}$ & $\mathbf{2 0 1 5}$ & $\mathbf{2 0 1 6}$ & $\mathbf{2 0 1 7}$ & $\mathbf{2 0 1 8}$ \\
\hline Total & $2,270,271$ & $2,292,834$ & $1,958,655$ & $2,204,400$ & $2,210,000$ \\
\hline Colleage enrollment & 269,988 & 219,885 & 91,559 & 230,400 & 219,800 \\
\hline Secondary enrollment & 301,605 & 303,854 & 147,096 & 310,000 & 325,200 \\
\hline Sum of Colleage \& Secondary & 571,593 & 523,739 & 238,655 & 540,400 & 545,000 \\
\hline $\begin{array}{l}\text { Primary enrollment and other vocational } \\
\text { training programs }\end{array}$ & $1,698,678$ & $1,769,095$ & $1,720,000$ & $1,664,000$ & $1,665,000$ \\
\hline
\end{tabular}

Source: The General Directorate of Vocational Training (2018)

Factors of ensuring vocational training quality are increasingly strengthened. The quality and efficiency of vocational training has been increased. Trained workers have participated in almost all sectors of the national economy and have taken on complicated positions and jobs that must have been undertaken by foreign experts before. Currently, over $85 \%$ of pupils and students have found jobs or created jobs by themselves immediately after their graduation. In some of occupations and vocational training institutions, this rate even reached $100 \%$.

To achieve these results, besides focusing on increasing investment in facilities, equipments, models, tools, etc. and organizing practice and intership courses, vocational training institutions have also implemented many other solutions. Specifically, vocational training institutions have increased hours of practices and internships to at least $70 \%$ of the total hours of each program; schools and students have paid more attention to the work of career counseling, guideline. Especially, schools have focused on practical models and internships in businesses and these 
have gradually become indispensable activities in the training process.

Currently, in the world, the cooperation model between training institutions and enterprises becomes very popular and effective, especially in developed countries. In Germany, this model is operated by a dual vocational training system, so that, learners will be practically trained at vocational training institutions and offices of enterprises. Accordingly, enterprises have tasks such as: participating in building career lists, standards and training programs; selecting, paying salary and training students; taking exams in competency assessments; being responsible for ensuring the vocational training quality. Similarly, the dual model of vocational training is also applied in most developed countries in the world such as England, France, United States of America, Japan, Australia, etc...

In the trend of international economic integration, "educational socialization" has become more and more popular in Vietnam. Inside the all relationships of society, the relationship between schools and enterprises plays a very important role. It helps the schools orient and organize its training activities so that learners can make practices and interships meanwhile schools can carry out train programs "based on demand" as wel as improve the quality, efficiency, scale of training step by step.

According to general assessments of the General Directorate of Vocational Training (2019b) on the cooperation situation between vocational training institutions and enterprises, there are many forms of cooperation in recent years and the role of enterprises has been shown in many aspects as follows: (i) Participating in developing training programs; (ii) Sending officials and experts to teach at the vocational training institutions; (iii) Participating in evaluating and organizing graduation examination of the vocational training institution; (iv) Receiving and guiding trainees at the enterprises; (v) Sending workers to study at vocational training institutions; (vi) Collaborating with vocational training institutions for training secondary, college and regular training programs; (vii) Supporting facilities and equipments for schools as well as granting scholarships for students and pupils to attend the schools; (viii) Receiving teachers from schools to visit and practice; (ix) Providing information on needs of training and labors as well as the recruitment of graduated students; (x) Giving feedback on the working quality of learners at their businesses (The General Directorate of Vocational Training, 2019).

Recognizing the importance of building a relationship between schools and enterprises, in Vietnam, the Ministry of Education and Training issued the Regulation on career guidance, job counseling in higher education and secondary institutions (Issued together with Decision No. 68/2008/QD-BGDDT of $9^{\text {th }}$ December, 2008 of the Minister of Education and Training). The Ministry of Labor, War Invalids and Social Affairs issued the Official Letter No.786/LDTBXH-TCGDNN dated $2^{\text {nd }}$ March, 2018 on linking vocational training with enterprises and also issued many guidelines and instructions to support schools. The Ministry of Education and Training and The Ministry of Labor, War Invalids and Social Affairs (the General Directorate of Vocational Training) also organized many seminars, summaries and meetings to discuss on building the relationship between the schools and enterprises. Both of ministries organized training programs on the topic of "Building training programs associated with business needs", etc.

\section{Literature Review}

Hoang (2016) said that the training of human resources of the training facilities are also to meet the needs of society and firms. Therefore, any training program should be viewed according to the law of labor supply and demand. The cooperation between enterprises and training institutions will have positive results.

Nguyen (2016) affirmed that the cooperation and cooperation program between universities and firms is the mission and interests of both sides, which must be maintained regularly. Universities need to collaborate with businesses to have more information seminars for students. The author also affirmed, the importance of linking training between universities and firms from the perspective of benefits for both sides.

According to Bach (2019), the success factors of the German vocational training system include: (i) The cooperation between the Government, the business community and social partners in sharing finance, updating and carry out training programs, assessing and issueing certificates; (ii) Learning at the workplace: Training at the enterprises as part of coordinated training programs (conducted in two places in schools and enterprises) with unified training regulations; (iii) Accepting national standards: Occupational standards and certificates are easily converted and equivalently accepted; (iv) Qualified vocational trainers: Vocational training staffs of enterprises and professional and pedagogical teachers of vocational training institutions; (v) Research and consultancy institutionalized: The labor market and the results of vocational training research are the basis for adjusting vocational training programs.

Bui (2019) argued that in recent years, the quality of vocational training in Vietnam still limited in the context of: (i) High rate of job movement; (ii) Student's lack of capacity and practice; (iii) The labor quality not met the business needs; (iv) The high unemployment rate.

\section{Research Methodology}

We used a qualitative research methodology based on some in-depth interviews with 3 lecturers with proficient in 
training, both of theoretical and practical. At the same time, we interviewed 3 experts working as Human resouces manager in firms. The results of the interviews include building the relationship between schools and enterprises. Based on the prior studies and results of qualitative research through expert interviews, we have conducted inductive method to verify, adjust and add attributes in questionnaires for collecting final data of the research.

Inheriting the results previous studies and using qualitative research methodology through interviews with experts. We identify building the relationship between schools and enterprises (BRBSE) including seven attributes as follows,

\begin{tabular}{|c|c|c|c|c|}
\hline Code & \multicolumn{4}{|c|}{ Variables and Its Attributes } \\
\hline \multicolumn{5}{|c|}{ Building the relationship between schools and enterprises (BRBSE) } \\
\hline BRBSE1 & \multicolumn{4}{|c|}{$\begin{array}{l}\text { Meeting the need of labor recruitment for businesses within a limited time (usually } 1 \text { week to } 2 \\
\text { months) }\end{array}$} \\
\hline BRBSE2 & \multicolumn{4}{|c|}{ Developing training programs based on the orders of the enterprises } \\
\hline BRBSE3 & \multicolumn{4}{|c|}{$\begin{array}{l}\text { Building a training model to suit with the recruitment requirements of the employers (immediately } \\
\text { meeting the recruitment requirements of enterprises at any time) }\end{array}$} \\
\hline BRBSE4 & \multicolumn{4}{|c|}{$\begin{array}{l}\text { Building a model of the division specialized in business relations to develop towards the direction } \\
\text { of labor supply service }\end{array}$} \\
\hline BRBSE5 & \multicolumn{4}{|c|}{$\begin{array}{l}\text { Developing a good mechanism to attract cooperation and to exploit the capacity of good experts } \\
\text { from businesses }\end{array}$} \\
\hline BRBSE6 & \multicolumn{4}{|c|}{$\begin{array}{l}\text { Building an appropriate cooperation mechanism and a training model to jointly exploit the potential } \\
\text { of facilities, equipment and technology of enterprises for the sake of practical teaching and } \\
\text { internship training }\end{array}$} \\
\hline BRBSE7 & \multicolumn{4}{|c|}{ Building a model for training quality management closed to the needs of the enterprises } \\
\hline \multicolumn{5}{|c|}{$\begin{array}{l}\text { Then, we have designed a questionnaire consisting of } 7 \text { variables with a 5-point Likert scale from } 1 \text { "not } \\
\text { totally agree" to } 5 \text { "fully agree". The method of data collection was accomplished through the survey and subjects } \\
\text { were the staff of training department of colleges, secondary schools and human resouces manager in firms. } \\
\text { We sent } 150 \text { questionnaires and received the feedback of } 135 \text {. After checking the information on the votes, } \\
\text { there were } 120 \text { questionnaires with full information for data entry and analysis, the size of this sample was } \\
\text { consistent with study of Gorsuch (1983). We used both qualitative and quantitative approaches for analysis data. } \\
\text { SPSS is a tool to support us to have descriptive statistics, Cronbach's Alpha were used for evaluating and measuring } \\
\text { the building the relationship between schools and enterprises. }\end{array}$} \\
\hline \multicolumn{5}{|c|}{$\begin{array}{l}\text { 4. Results and Discussion } \\
\text { 4.1. Descriptive Statistics }\end{array}$} \\
\hline \multicolumn{5}{|c|}{ able 2: Personal characteristics of the participants } \\
\hline & & Frequency & Percent & Cumulative Percent \\
\hline \multicolumn{5}{|l|}{ Gender } \\
\hline \multicolumn{2}{|l|}{ Male } & 64 & 53.3 & 53.3 \\
\hline \multicolumn{2}{|l|}{ Female } & 56 & 46.7 & 100.0 \\
\hline \multicolumn{5}{|c|}{ Work experience } \\
\hline \multicolumn{2}{|c|}{ Over 5 years } & 69 & 57.5 & 57.5 \\
\hline \multicolumn{2}{|c|}{ To 5 years } & 51 & 42.5 & 100.0 \\
\hline & Total & 120 & 100.0 & \\
\hline
\end{tabular}

Table 2 shows that among the 120 respondents, $53.3 \%$ of the participants were male while the remaining 56 were female, representing for $46.7 \%$. Of these, $42.5 \%$ of the participants have work experiences for 5 years or less, and over 5 years accounted for $57.5 \%$.

Table 3: Descriptive Analysis of Attributes of the Building the relationship between schools and enterprises

\begin{tabular}{|c|c|c|c|c|c|}
\hline & $\mathrm{N}$ & Minimum & Maximum & Mean & Std. Deviation \\
\hline BRBSE1 & 120 & 2.0 & 5.0 & 3.525 & .8596 \\
\hline BRBSE2 & 120 & 1.0 & 5.0 & 3.642 & .9056 \\
\hline BRBSE3 & 120 & 2.0 & 5.0 & 3.583 & .866 \\
\hline BRBSE4 & 120 & 2.0 & 5.0 & 3.625 & .800 \\
\hline BRBSE5 & 120 & 2.0 & 5.0 & 3.833 & .726 \\
\hline BRBSE6 & 120 & 2.0 & 5.0 & 3.800 & .894 \\
\hline BRBSE7 & 120 & 2.0 & 5.0 & 3.867 & .829 \\
\hline Valid N (listwise) & $\mathbf{1 2 0}$ & & & $\mathbf{3 . 6 9 6}$ & \\
\hline
\end{tabular}

Data in Table 3 illustrate that the respondents agreement with the dependent variables of "Building the relationship between schools and enterprises" where seven attributes were quite high with an average of 3.696 compared with the highest of the Likert 5-point scale. All 7 attributes were rated at an average of 3.525 or higher. 


\subsection{Testing Cronbach's Alpha}

The building the relationship between schools and enterprises has been measured by the Cronbach's Alpha with coefficient of 0.733 . Results of testing Cronbach's alpha of attributes are presented in Table 4 as follows,

Table 4: Results of Cronbach's Alpha Testing of Attributes

\begin{tabular}{|c|c|c|c|c|}
\hline & $\begin{array}{c}\text { Scale Mean if } \\
\text { Item Deleted }\end{array}$ & $\begin{array}{c}\text { Scale Variance if } \\
\text { Item Deleted }\end{array}$ & $\begin{array}{c}\text { Corrected Item- } \\
\text { Total Correlation }\end{array}$ & $\begin{array}{c}\text { Cronbach's Alpha } \\
\text { if Item Deleted }\end{array}$ \\
\hline BRBSE1 & 22.350 & 6.313 & .394 & .697 \\
\hline BRBSE2 & 22.233 & 5.710 & .315 & .629 \\
\hline BRBSE3 & 22.292 & 5.536 & .394 & .687 \\
\hline BRBSE4 & 22.250 & 5.971 & .328 & .631 \\
\hline BRBSE5 & 22.042 & 7.570 & .311 & .697 \\
\hline BRBSE6 & 22.075 & 6.608 & .315 & .704 \\
\hline BRBSE7 & 22.008 & 6.714 & .314 & .726 \\
\hline
\end{tabular}

The results also show that attributes of the dependent variables had a Cronbach's Alpha coefficient greater than 0.6 and were less than the common Cronbach's Alpha coefficient; the correlation coefficient of all attributes was greater than 0.3 , so all the attributes of the dependent variables were statistically significant (Hoang \& Chu, 2008; Hair et al, 2009).

\section{Discussion}

\subsection{Characteristics of vocational training schools}

Firstly, schools are the places with the young labor force that have the same capacity and is well organized and trained. These objects can be disseminated with information and quickly mobilized with a low cost.

Secondly, the schools have a legal status and certain prestige with the learners, learners' families and the community.

Thirdly, the schools have facilities, teachers, capacity to organize training programs in many fields and levels. They are also quite professional in organizing training programs in most types of businesses by themselves.

Fourthly, students in secondary schools spend over $70 \%$ time for their practice and intership. If they are able to combine practice with working in enterprises, they will have many opportunities to help enterprises reduce costs of labor and production.

Fifthly, schools are often the places where gather many good experts to advise, support or directly undertake important positions at the enterprises, transfer technology or help enterprises quickly access with new technologies...

\subsection{Characteristics of enterprises}

Firstly, it must be affirmed that the enterprises are the largest customers for training products of all schools. Therefore, the schools have a responsibility to find ways to meet the requirements and to recognize positive and negative feedbacks on the quality of training products from the businesses. Enterprises can make the most honest recommendations about the quality of trained labor and determination of job positions, training programs, output standards and training methods of schools.

Secondly, enterprises have facilities, equipments, updated technologies which are organized with a larger scale, higher efficiency and closed to practical models in schools. If students practice in businesses, schools will save much funding for infrastructure investment, practical equipment and find easy to change careers and expand training scale.

Thirdly, businesses also attract many good and high skill experts. This is the source of high quality experts and lecturers to help ensure and improve the training quality of the school.

Fourthly, the labor force in enterprises always in needs of re-training and advancedly training to respond to very rapid changes in technology. Therefore, businesses are also customers that provide very effective input for schools (because of obtained benefits from financial capacity of the business is stronger than that of individual learners)... Schools and businesses cooperationg closely in many fields will create conditions for promoting their full potential and complementing each other with new potentials. All these will create conditions for them to develop.

\section{Recommendations}

\subsection{For the schools}

First, creating consensus of teachers in the schools

The motto "On-demand training", "Accompanying with enterprises", "Considering learners the center"... must become a common policy, an action slogan and a successful determination to all teachers and staffs of the schools. Second, actively, proactively establishing and operating win-win relationships between schools and businesses Specifically, schools and businesses have to answer two questions in their cooperation: "What must they do?" and 
"What will they receive?". In particular, they should pay more special attention to the interests of learners. Schools do not pay attention to profit in cooperation with businesses. Especially, students to work at bussiness should be implemented without fee.

Third, bring into full play the comparative advantages of each school

Taking advantage of the direction and high support of leaders at all levels, especially the Ministry of Labor, War Invalids and Social Affairs and its departments.

Taking advantage of geographical locations.

Fourth, strictly implementing the motto of "On-demand training"

Meeting the needs of training and labor use of enterprises.

Meeting the needs of learners about the majors, especially implementing various methods and forms of training so that students have more choices to study. Ensuring students to learn and work as well as get income to pay for their daily life.

Fifth, forming units to to perform the work

The Business Relationship Department or the Business Relationship Team becomes important parts in establishing and operating the relationships between the schools and the businesses.

Selecting staff members to undertaking the task of establishing and operating the relationship between the schools and businesses.

Sixth, relations between schools: Schools need to establish and operate cooperation relationships, share experiences, and coordinate to meet the needs of businesses in particular and the labor market in general.

Seventh, training foreign languages: Foreign language is a tool to help work effectively and to increase labor productivity. Therefore, requiring students to learn foreign languages become indispensable needs of the schools. Particularly, labor-transfering occupations in the ASEAN ecomic community and occupations of the Government of Vietnam have signed a technical agreement on trainees and labor export to traditional and potential markets.

\subsection{For the Ministry of Labor, War Invalids and Social Affairs}

The Ministry of Labor, War Invalids and Social Affairs of Vietnam has specific plans and coordinates with the Ministry of Education and Training, as well as relevant ministries and sectors to create a more favorable legal corridor for schools in developing relationships with businesses. It is nescessary to establish clear regulations and specific guidelines to create favorable conditions for schools to access and receive grants from domestic and foreign organizations and individuals. So that, these schools have enough facilities and financial resources for good effectiveness of vocational employment, training, counseling and career guidelines.

It is necessary to have regulations, directives, guidelines, encouragement and reward for businesses in actively establishing and operating relationships with the schools.

\section{Conclusion}

The nature of the coherent relationship between vocational training and enterprises is benefit. They must get benefits in cooperation to strengthen their relationship. In fact, the benefits need to be harmoniously satisfied for both sides and the relevant third parties (learners, learners' families, relevant agencies, units, communities). First, schools need to understand what they have for business needs and what their needs from the businesses. Second, schools have to find ways to improve and present their competencies to businesses (potential customers). They should also convince businesses to believe that in their corporations there is nothing better than effectively completing their commitments (response time, service quality and training products, disbursement capacity).

\section{References}

Bach, H. T. (2019). Cooperation between businesses and vocational training: Experiences and practices. Presentations. Workshop on evaluating results of vocational training and enterprises in 2019, proposing tasks and solutions for 2020. The General Department of Vocational Education.

Bui, T. M. (2019). Enhancing the role of businesses to improve vocational training quality. Presentations. Workshop on evaluating results of vocational training and enterprises in 2019, proposing tasks and solutions for 2020. The General Department of Vocational Education.

Gorsuch, R. L. (1983), Factor Analysis 2nd Ed.., Hillsdale, NJ: Erlbaum.

Hair, J. F., Black, W. C., Babin, B. J., \& Anderson, R. E. (2009). Multivariate Data Analysis (7th ed.). Upper Saddle River, NJ: Prentice Hall International.

Hoang, T., \& Chu, N.M.N (2008). Analysis of research data with SPSS. Hong Duc Publishing House.

Hoang, V. L. (2016). The relationship between schools and businesses meets the requirements of advanced school construction at Ho Chi Minh City Transport College. Journal of vocational training (Vietnam), 35, 13-15.

Nguyen, V. H. (2016). The relationship between university and business. Journal of education Management, 8(9), $39-44$.

The General Directorate of Vocational Training (2018). Summary Report for the school year 2018 and tasks for 
2019.

The General Directorate of Vocational Training (2019a). Summary Report for the school year 2019 and tasks for 2020.

The General Directorate of Vocational Training (2019b). Report on strengthening the link between vocational training and business in 2019 and tasks and solutions in 2020 